\title{
The Possible Ameliorating Effect of Barley Grain on the Histological Structure of the Adrenal Cortex in Streptozotocin (STZ)-induced Diabetes in Adult Male Albino Rats
}

Original Article

\author{
Mona A. Soliman and Dalia A. Noya
}

Histology and Cell Biology Department, Faculty of Medicine, Menoufia University, Egypt

\begin{abstract}
Background: Diabetes is one of the most common endocrine disorders caused by lack of, or reduced insulin action leading to increase in blood glucose level and metabolic disorders in the body. Diabetes causes severe degeneration within the cells of adrenal cortex. Barley grain is known to be beneficial in regulating sugar, insulin, and cholesterol responses to foods. However, studies about its effect on the structure of adrenal cortex in diabetes are limited.

Objective: This work aimed to evaluate the possible protective effect of barley grain on the histological changes within the adrenal cortex in streptozotocin-induced diabetes in adult male albino rats.

Materials and Methods: Forty adult male albino rats were used in the study. They were divided into four groups of ten each: group I was the control group; group II received barley grain extract intragastrically; group III included rats with streptozotocin (STZ)-induced diabetes; and group IV received barley green extract after inducing diabetes. After 12 weeks, Rats were sacrificed by using ether anesthesia. Blood plasma was collected for hormonal analysis then adrenal tissue was used for histological and immunohistochemical studies.

Results: STZ-induced diabetes resulted in a significant decrease in body weight and serum aldosterone and corticostrione levels and significant increase in adrenal weight. The cells of adrenal cortex appeared disorganized. Their nuclei appeared pyknotic with vacuolated cytoplasm. The blood sinusoids in-between the cells of adrenal cortex appeared dilated and congested. Distorted smooth endoplasmic reticulum and degenerated (mouse- bitten) mitochondria were also detected within the cells. Administration of barley grain after induction of diabetes led to amelioration of these changes.

Conclusion: Barley grain extract administration improved the histological and biochemical changes induced by diabetes in adrenal cortex.
\end{abstract}

Received: 17 September 2019, Accepted: 21 October 2019

Key Words: Adrenal cortex, barley grain, diabetes, streptozotocin.

Corresponding Author: Dalia A. Noya, M.D., Histology and Cell Biology Department, Faculty of Medicine, Menoufia University, Egypt, Tel.: +20 1068464307, E-mail: dalia_noya@yahoo.com

ISSN: 1110-0559, Vol. 43, No.2

\section{INTRODUCTION}

Diabetes is believed to be one of the fastest growing diseases in the world ${ }^{[1]}$. It is one of the most common endocrine disorders that results from lack of, or reduced insulin action leading to increase in blood glucose level and metabolic disorders in the body ${ }^{[2]}$. Induction of experimental diabetes occurs by chemical destruction or surgical removal of part of the beta cells of the pancreas, feeding with high-fat and high sugar diets and drugs such as streptozotocin (STZ) and alloxan. Streptozotocin leads to destruction of pancreatic beta cells which finally ends with insulin deficiency similar to that of human diabetes type $\mathrm{I}^{[3]}$.

Adrenals are considered as the most important endocrine glands which are involved in many biological functions including developmental, immune, inflammatory, osmoregulatory and metabolic activities ${ }^{[4]}$. Adrenal hormones directly affect the metabolic adjustments of carbohydrates, proteins and lipids; thus, influencing the functional status of all major organs of the body including heart, kidney, bones, muscles and nervous system ${ }^{[5]}$.

Studies illustrated the effects of diabetes on the adrenal gland showed that diabetes causes severe degeneration within the cells of zona glomerulosa and zona fasciculate of adrenal cortex ${ }^{[6,7]}$.

Barley (Hordeum vulgare) belongs to the grass family, Poaceae (Gramineae). It is considered as the fourth most essential cereal crop after wheat, maize and rice ${ }^{[8]}$.

Some authors demonstrated that the insoluble fiber found in barley helps the regulation of bowl function and also may help decreasing the risk for cancers; in addition, barley contains antioxidants that reduce the rate of oxidative damage by scavenging free radicals ${ }^{[9]}$.

The work of some scientists reported that soluble fiber, such as $\beta$-glycan, found in barley may be beneficial in regulating sugar, insulin, and cholesterol responses to foods ${ }^{[10]}$. History of barley consumption in the diet 
indicates this plant's lack of toxicity ${ }^{[1]}$. Barley also has hepatoprotective and hypolipidemic effects ${ }^{[12]}$.

\section{MATERIALS AND METHODS}

\section{Animals}

Forty adult male albino rats of average weight 180-220grams, aged 10-12 weeks were used in the experiment. The animals were obtained from the animal house at Faculty of Medicine, Menoufia University one week before the start of the experiment to be acclimatized with the laboratory conditions. The rats were kept in healthy standard environmental conditions at room temperature having free access to laboratory rat chow diet and water ad-libitum.

The rats were chosen of the same sex (male) to exclude any possible effect of hormones and of the same age group to avoid any possible changes within the structure of adrenal cortex.

\section{Chemicals}

Streptozotocin was obtained from sigma chemical company in the form of powder. It was dissolved in freshly prepared citrate buffer at $\mathrm{pH} 4$. Barley grain obtained from local grocery in Sheibin El-kom Menoufia was prepared in the form of aqueous extract by the following procedure.

Preparation of aqueous extract of barley grain: barley grains were cleaned, dried and grounded into a fine powder then boiling distilled water was added to the powder (10 gm of barley/100 ml water). Powder was soaked in boiled water for 6 hours then filtered through a sieve and stored in dark bottles immediately ${ }^{[13]}$.

\section{Experimental Procedure}

The rats were randomly divided into four groups included 10 animals for each:

Group I (control group): the animals of this group kept without any treatment.

Group II (barley grain treated group): the animals received aqueous extract of barley grain at a dose of $13 \mathrm{ml} /$ $\mathrm{kg}$ body weight daily by gastric tube. Each animal received $2.5 \mathrm{ml}$ daily of aqueous extract of barely grain by gastric tube ${ }^{[13]}$ for 12 weeks.

Group III and Group IV (The experimental groups): the animals were fasted overnight then were injected intra-peritoneally with streptozotocin as diabetogenic agent at a dose of $37 \mathrm{mg} / \mathrm{kg}$ of body weight. Each animal received a single intraperitoneal injection at a dose of $1 \mathrm{ml}$ of freshly made solution of streptozotocin immediately prepared 10 minutes before injection by dissolving $74 \mathrm{mg}$ of streptozotocin in freshly prepared $10 \mathrm{ml}$ of citrate buffer at $\mathrm{pH} 4$ to avoid the instability of STZ in solution ${ }^{[1]}$.

After the injection, the rats had free access to glucose solutions $(5 \%)$ for 24 hours to avoid the expected hypoglycemic shock. Seventy-two hours after the injection, tail blood samples from overnight fasting rats were obtained to measure blood glucose level. Rats with blood glucose levels above $250 \mathrm{mg} / \mathrm{dl}$ were considered as diabetic animals and were chosen. After confirming the diabetic status, animals of group III kept without any treatment for 12 weeks while animals of group IV received aqueous extract of barley grain at a dose of $13 \mathrm{ml} / \mathrm{kg}$ body weight daily by gastric tube ${ }^{[13]}$ for 12 weeks. During the experiment the blood glucose level was measured for all groups (group I, II, III and IV) at $4^{\text {th }}, 8^{\text {th }}$, and $12^{\text {th }}$ weeks.

Twenty-four hours after the last dose, all animals were weighted and then sacrificed after being anesthetized by an intraperitoneal injection of $40 \mathrm{mg} / \mathrm{kg}$ pentobarbital sodium $^{[14]}$. The blood samples were collected to measure the serum levels of aldosterone and corticosterone hormones. The adrenal glands were carefully dissected, excised, weighted then washed with normal saline. The tissues were subjected to the following studies:

\section{Light Microscopic Studies}

\section{Histological Study}

One adrenal gland of each animal was fixed in $10 \%$ formol saline, dehydrated, cleared and embedded in paraffin wax. Five $\mu \mathrm{m}$ thickened sections were cut and stained with haematoxylin and eosin $(\mathrm{Hx} \& \mathrm{E})$ for routine histological examination of general architecture of adrenal cortex $^{[15]}$ and Mallory's Trichrome stain for detection of collagen fibers ${ }^{[16]}$.

\section{I- Immunohistochemical study}

For caspase 3 stain, paraffin sections of $5 \mu \mathrm{m}$ thickness were mounted on glass slides coated on pol-L-lysine, de-paraffinized using xylene, dehydrated and then put in $10 \mathrm{ml}$ sodium citrate buffer. To block endogenous peroxidase, sections were heated in a microwave oven at $60{ }^{\circ} \mathrm{C}$ for 15 minutes. The slides were primarily treated with trypsin solution $(1 \mathrm{mg}$ in $150 \mathrm{ml}$ Tris-HCL, $0.05 \mathrm{M}, \mathrm{pH} 7.6$ ) for 15 minutes at room temperature. Activated caspase-3 expression was revealed using a peroxidase-conjugated rabbit monoclonal antibody IgG (Cell signaling Technology, Ipswich, MA) at dilution 1:200. Slides were washed and incubated at room temperature for 30 minutes with streptavidin biotin peroxidase complex. Finally, the sections were counter stained with Mayer's hematoxylin. Normal lymphoid tissue was used as positive control. Negative control was performed by omitting primary antibody step consequently no immune- staining was found ${ }^{[17]}$.

\section{II- Electron Microscopic study}

The other adrenal gland was rapidly cut into small pieces $(1 \mathrm{~mm})$, and then was immediately fixed in $3 \%$ glutaraldehyde buffered with $0.1 \mathrm{~mol} / \mathrm{L}$ PBS at $\mathrm{pH} 7.4$ for 3 hours at $4{ }^{\circ} \mathrm{C}$ and post fixed in $1 \%$ osmium tetroxide in the same buffer for 2 hour at $4{ }^{\circ} \mathrm{C}$. The tissue were then dehydrated in ascending grades of alcohol, and embedded in epoxy resin. . Ultrathin sections were stained with uranyl acetate and lead citrate to be examined and 
photographed using transmission electron microscope TEM (JEOL,JEM-2100, Tokyo, Japan) ${ }^{[18]}$ in the Faculty of Agriculture, El-Mansoura University, El-Mansoura, Egypt.

\section{III-Hormonal Assay}

Blood samples collected before scarification of the animals under anesthesia were centrifuged, and then the serum was separated to measure the levels of aldosterone and corticosterone hormones. This was done in central lab, Faculty of Medicine, Menoufia University.

Statistical analysis: the body weight (g.), adrenal weight (mg.), serum aldosterone $(\mu \mathrm{g} / \mathrm{dl})$ and serum corticosterone level $(\mu \mathrm{g} / \mathrm{dl})$ data were expressed as mean $\pm \mathrm{SD}$. The student t-test was used to evaluate the significant change in each parameter in the experimental groups (group III and IV) when compared to the control group (group I) and comparing streptozotocin treated group (group III) with barley grain and streptozotocin treated (group IV). The statistical analysis of data was carried out using Excel and statistical package for the social science software, version 11. In all statistical analysis $P<0.05$ was taken as the level of significance, $P$ value $>0.05$ was considered non-significant and $P$ value $<0.001$ was considered highly significant ${ }^{[19]}$.

\section{RESULTS}

\section{Light Microscopic Results}

\section{Group I (Control Group)}

Sections of adrenal gland of (group I) control group showed connective tissue capsule covering the surface of the gland. The gland consisted of outer cortex and inner medulla. The adrenal cortex consisted of three zones: zona glomrulosa, zona fascuilata and zona reticularis. Zona glomerulosa (ZG) consisted of closely packed cells with spherical densly packed nuclei arranged in the form of rounded arches beneath the capsule. These arches were seperated from each others by blood sinusoids. Zona fasciculata (ZF) had long straight parallel cords of cells seperated by longtiudinally arranged blood sinusoids. These cells were polyhedral having vaculated cytoplasm with large vesicular nuclei (Figures 1 and 2).

The innermost part of the adrenal cortex close to medulla was zona reticularis (ZR). It consisted of branching cords of small cells with deeply stained nuclei seperated by blood sinusoids. Adrenal medulla appeared formed of anastomosing cords of large chromaffin cells with large vesicular nuclei and basophilic cytoplasm (Figure 3).

Mallory's trichrome stained sections had moderate amount of collagen fibers forming the capsule surrounding the gland with minimal amount of collagen fibers appearing between the arches of zona glomerulosa (Figure 4).

Caspase-3 immunostaining: adrenal sections from control group revealed negative cytoplasmic immunoreactivity for caspase -3 in cells of adrenal cortex (Figure 5)

\section{Group II (Barley grain treated group)}

Group II (Barley grain treated group) revealed similar histological results as the control group.

\section{Group III (Streptozotocin treated group)}

Adrenal sections of this group showed corrugation of the capsule surrounding the adrenal gland with sepration of its fibers. Blood vessels within the capusle appeared dilated and congested. The cells of zona glomerluosa appeared disorganized with pyknotic nuclei.The cells of zona fasciculata were disarranged with pyknotic nuclei and vacuolated cytoplasm. The blood sinusoides in-between the cells appeared dilated and congested (Figures 6,7,8 and 9 ). The blood sinusoids within zona reticularis appeared dilated and congested (Figure 10).

Mallory's trichrome stained sections showed apparent thickening of the capsule surrounding the gland with wide spaces between its collagen fibers (Figure 11).

Caspase-3 immunostaining: adrenal sections from this group showed strong positive cytoplasmic immunoreactivity for caspase -3 in cells of adrenal cortex (Figure 12).

\section{Group IV (Barley grain and streptozotocin treated group)}

Adrenal sections of this group revealed nearly normal capsule surrounding the gland with minimal seperation between its fibers. The cells of different zones of adrenal cortex appeared more or less normal but some vacuoles remained within these cells (Figure 13). Few blood sinusoides inbetween cells of zona reticularis appeared dilated and congested (Figure 14).

Mallory's trichrome stained sections showed moderate amount of collagen fibers forming the capsule surrounding the gland (Figure 15).

Caspase-3 immunostaining: adrenal sections from this group showed mild positive cytoplasmic immunoreactivity for caspase -3 in cells of adrenal cortex (Figure 16).

\section{Electron Microscopic Results}

\section{(Group I) Control Group}

Ultrathin sections of adrenal gland of control group showed that the adrenal gland was surrounded with capusle consisting of collagen fibers with multiple fibroblasts inbetween. The fibroblasts had oval nuclei with normal contour and ecchogenicity (Figure 17).

The cells of zona glomerulosa had rounded or oval nuclei en-sheathed with double layered nuclear envelope having peripheral dense heterochromatin. Their cytoplasm showed numerous mitochondria varying from oval to spherical in shape with tubular cristae, multiple lipid droplets and rosette shaped electron-dense glycogen granules. The cells were joined together with desmosome junction (Figures 18 and 19). 
Beneath zona glomerulosa, the cells of zona fasciculata appeared having rounded nuclei surrounded by double layered regular nuclear envelope. Their cytoplasm showed many mitochondria with tubular cristae and smooth endoplasmic reticulum (Figure 20).

\section{Group II (Barley grain treated group)}

Group II (Barely grain treated group) revealed similar electron microscopic results as that of control group.

\section{Group III (Streptozotocin treated group)}

Ultrathin secions of group III (Streptozotocin treated group) revealed capsule surrounding the adrenal gland. Its collagen fibers were plenty close to and near by the fibroblast. The fibroblasts appeared active with euchromatic nuclei (Figure 21).

The cells of zona glomerluosa had shrunken nuclei with dilation of perinuclear space. Some mitochondria appeared swollen while others appeared degenerated. Lipid droplets appeared with variable degrees of saturation. In between the cells, some blood sinusoids appeared congested. Others had large lytic area containing RBCs (Figures 22, 23 and 24).

The cytoplasm of cells of zona fasciculata appeared vacuolated and disorganized smooth endoplasmic reticulum was also detected. The mitochondria showed partial (mouse beaten) and complete degeneration (Figures 25 and 26).

\section{Group IV (Barley grain and streptozotocin treated group)}

Ultrathin secions of group IV ( Barley grain and streptozotocin treated group) revealed more or less normal capsule surrounding the adrenal gland consisting of normal fibroblasts having normal nuclei with collagen fibers in between .The cells of zona glomerluosa had normal nuclei, normal mitochondria and lipid droplets (Figures 27 and 28).

The cells of zona fasciculata had normal euchromatic nuclei. Their cytoplasm had apparently normal globular mitochodria, well structured smooth endoplasmic reticulum and well developed golgi apparatus (Figure 29).

\section{Quantitative and Statistical Results}

\section{Blood Glucose Level (mg/dl)}

At the $4^{\text {th }}, 8^{\text {th }}$ and $12^{\text {th }}$ week's measurements of blood glucose level, group III (Streptozotocin treated rats) showed highly significant increase in the mean blood glucose level as compared with the group I (control group) (P value $<0.001)$. Group II (Barley grain treated group) and group IV (barley grain and streptozotocin treated group) showed non-significant difference in the mean blood glucose level as compared with group I (control group) $(P$ value $>0.05)$. Group IV (Barley grain and streptozotocin treated group) showed highly significant decrease in the mean blood glucose level as compared with group III (streptozotocin treated group) $(P$ value $<0.001)$ as seen in (Table 1).

\section{The body weight in grams}

Group III (Streptozotocin treated group) showed highly significant decrease in mean body weight as compared with group I (control group) (P value $<0.001)$. Group II (Barley grain treated group) and group IV (Barley grain and Streptozotocin treated groups) showed non-significant decrease in the mean body weight as compared with group I (control group) (P value $>0.05)$. Group IV (Barley grain and Streptozotocin treated groups)showed highly significant increase in the mean body weight as compared with group III (streptozotocin treated group) $(P$ value $<0.001)$ as seen in (Table 2 and Diagram 1).

\section{The adrenal weight in milligram (mg)}

Group III (Streptozotocin treated group) showed highly significant increase in mean adrenal weight as compared with the group I (control group) ( $P$ value $<0.001)$. Group II (Barley grain treated group) and group IV (barley grain and streptozotocin treated group) showed non-significant increase in the mean adrenal weight as compared with group I (control group) ( $P$ value $<0.05)$. Group IV (Barely grain and streptozotocin treated group) showed highly significant decrease in the mean adrenal weight as compared with group III (streptozotocin treated group) $(P$ value $<0.001)$ as seen in (Table 3 and Diagram 1$)$.

\section{Hormonal Assay Results}

Group III (Streptozotocin treated group) showed highly significant decrease in mean serum aldosterone level as compared with group I (control group) ( $P$ value $<0.001)$. Group II (Barley grain treated group) and group IV (Barley grain and streptozotocin treated group) showed non-significant decrease in the mean serum aldosterone level as compared with group I (control group) $(P$ value $>0.05)$. Group IV (Barely grain and streptozotocin treated group) showed highly significant increase in the mean serum aldosterone level as compared with group III (streptozotocin treated group) $(P$ value $<0.001)$ as seen in (Table 4 and Diagram 1).

Group III (Streptozotocin treated group) showed highly significant decrease in mean serum corticosterone level as compared with the group I (control group) (P value $<0.001)$. Group II (Barley grain treated group) and group IV (Barley grain and streptozotocin treated group) showed nonsignificant decrease in the mean serum corticosterone level as compared with group I (control group) (Pvalue $>0.05)$. Group IV (Barley grain and streptozotocin treated group) showed highly significant increase in the mean serum corticosterone level as compared with group III (streptozotocin treated group) $(P$ value $<0.001)$ as seen in (Table 5 and Diagram 1). 


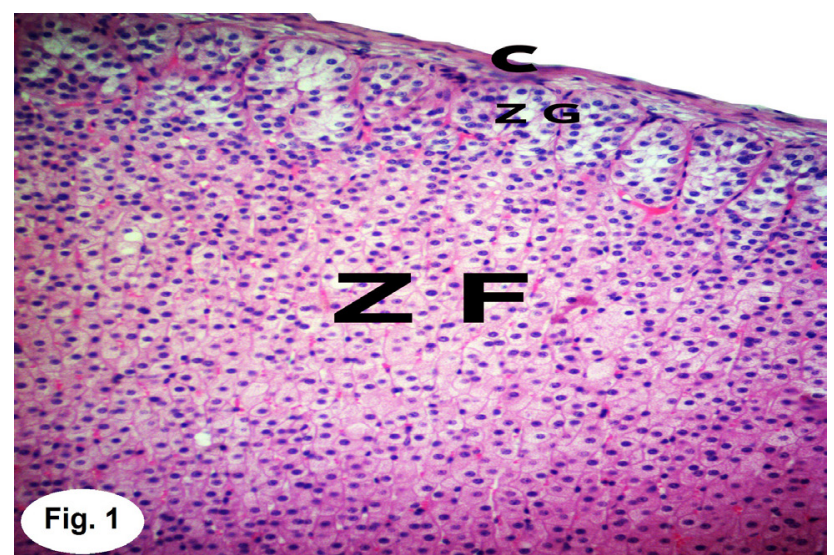

Fig. 1: A photomicrograph of control adrenal cortex showing connective tissue capsule (C) surrounding the gland. The zona glomerulosa (ZG) is formed of arched clusters of cells with densely packed nuclei. Underneath zona glomerulosa, there is Zona fasciculata (ZF) consisted of long straight parallel cords of cells with vesicular nuclei Group I (H. \&E. x 200)

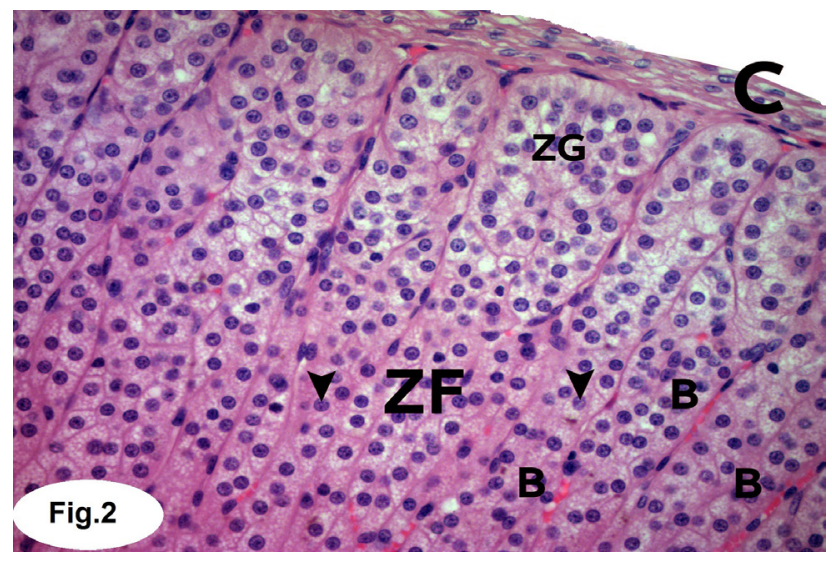

Fig. 2: Higher magnification of the previous image showing capsule (C) and arched clusters of cells forming zona glomerulosa (ZG). The cells of zona fasciculata (ZF) are arranged in long straight parallel cords of polyhedral cells with vesicular rounded nuclei (arrow head) separated by longitudinally arranged blood sinusoids (B). Group I (H. \& E. x 400)

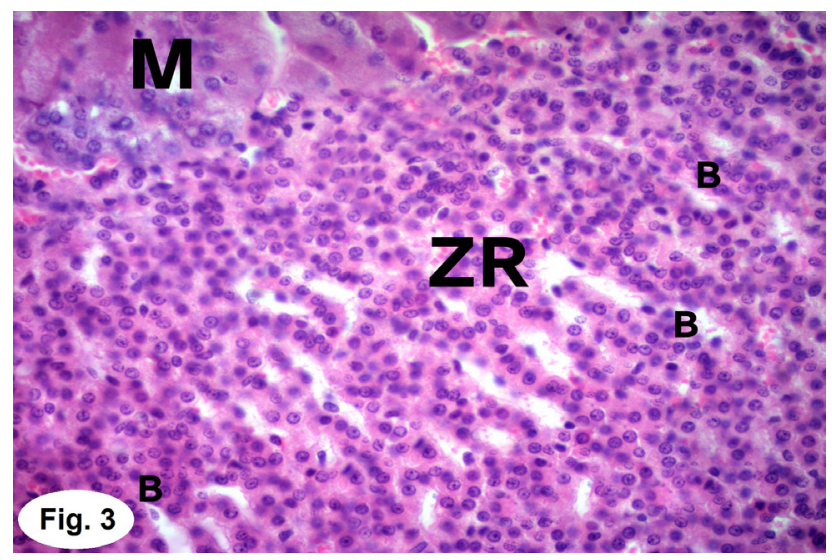

Fig. 3: A photomicrograph of central part of control adrenal gland showing part of zona reticularis (ZR) formed of anastomosing cords of closely packed cells with deeply stained nuclei separated by small blood sinusoids (B). Adrenal medulla (M) is noticed formed of anastomosing cords of large chromaffin cells with large vesicular nuclei. Group I (H. \&E. $x$ 400)

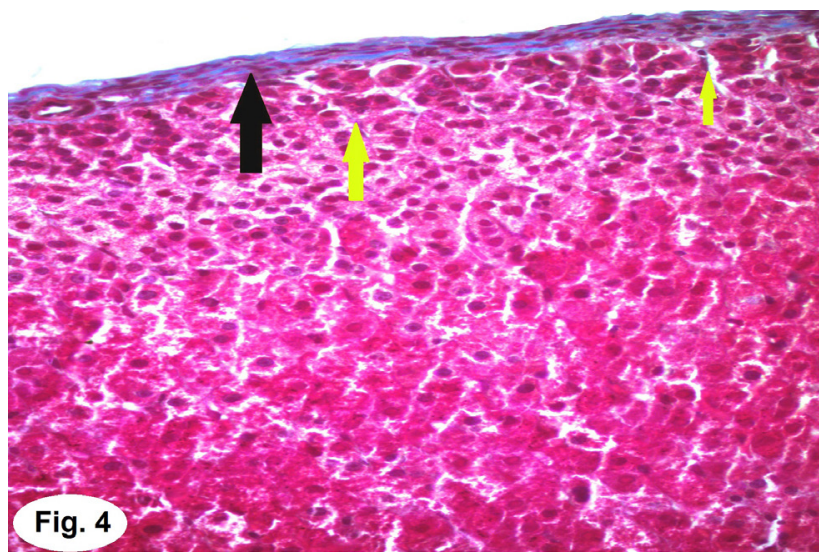

Fig. 4: A photomicrograph of control adrenal cortex showing average amount of collagen fibers forming the capsule (black arrow) surrounding the gland with minimal amount of collagen fibers (yellow arrow) appearing between the arches of zona glomerulosa. Group I (MT x 400)

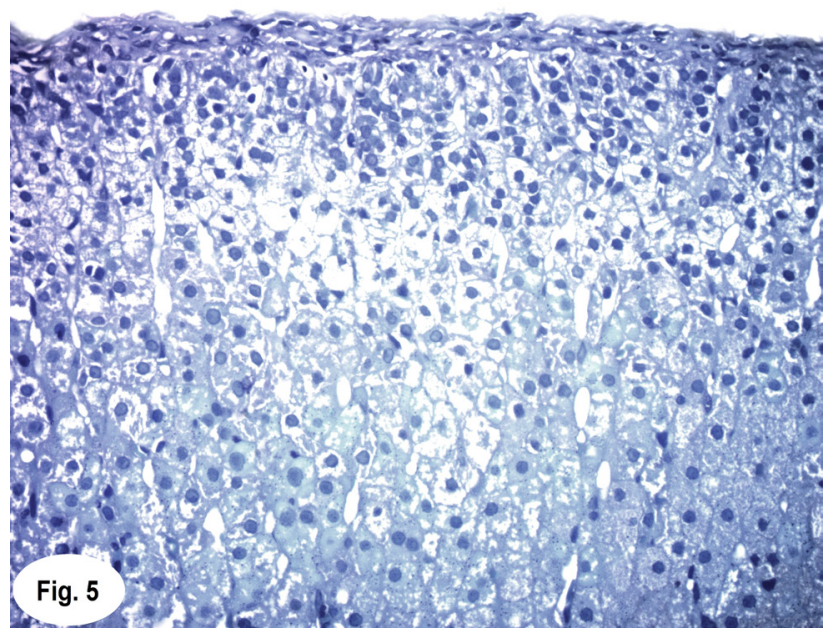

Fig. 5: A photomicrograph of control adrenal cortex showing negative cytoplasmic immunoreactivity for caspase- 3 within the cells of adrenal cortex. Group I (Caspase-3 x 400)

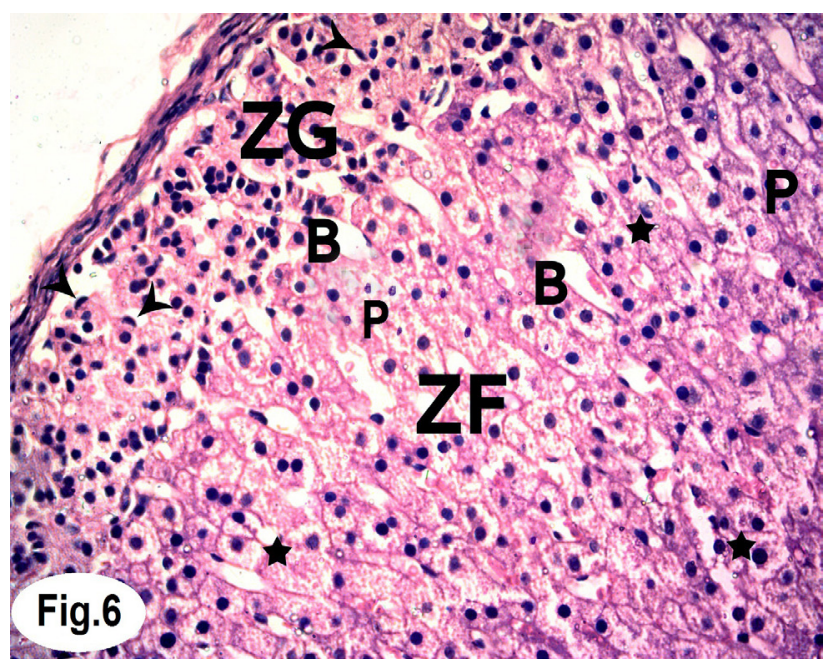

Fig. 6: A photomicrograph of adrenal cortex of adult male albino rat treated with streptozotocin showing disorganized zona glomerulosa (ZG) cells appears vacuolated (star) with pykontic nuclei (P). Dilated blood sinusoids (B) are noticed in-between. Group III (H. \& E. x400) 


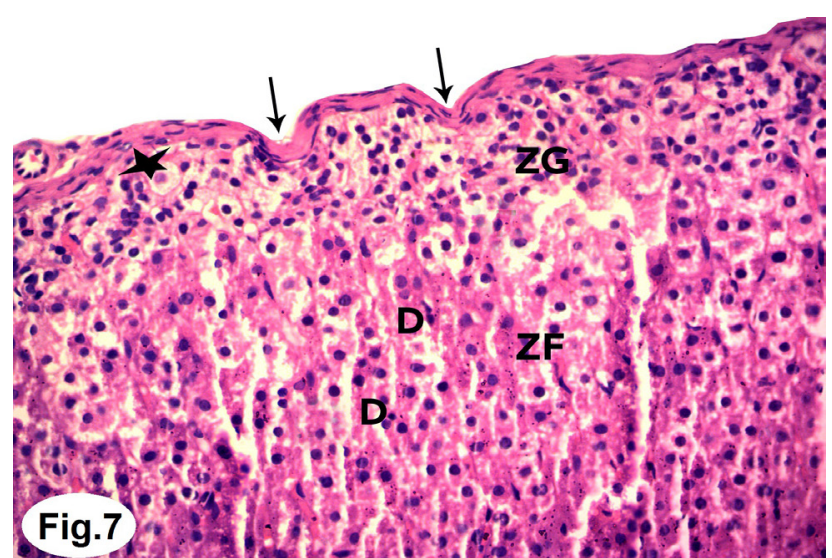

Fig. 7: A photomicrograph of adrenal cortex of adult male albino rat treated with streptozotocin showing corrugation of the capsule (arrow) Some cells of zona glomerulosa (ZG) appear ballooned (star) with degenerated nuclei. The cells of zona fasciculata (ZF) appear disarranged. Some of their nuclei appeared deeply stained (D). Group III (H. \& E. x 400)

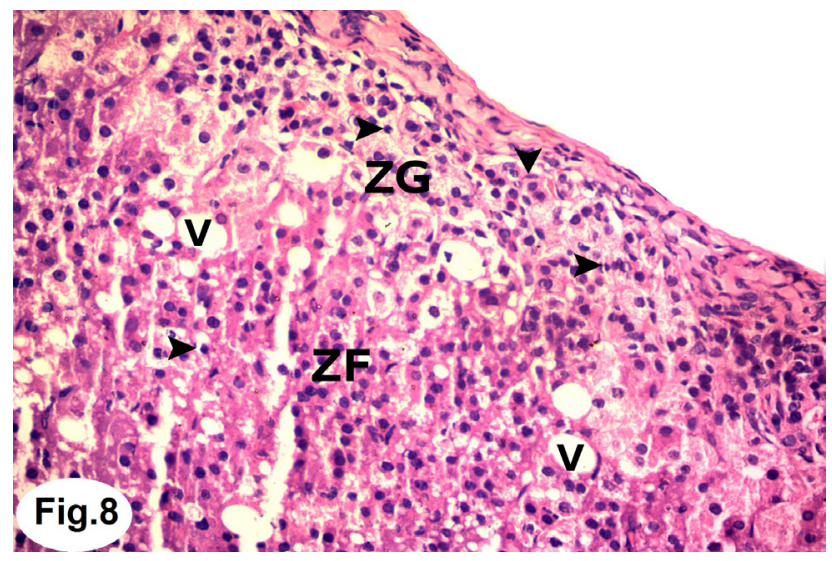

Fig. 8: A photomicrograph of adrenal cortex of adult male albino rat treated with streptozotocin showing disorganization of cells of zona glomerulosa ( ZG) and zona fasciculata (ZF) with deeply stained nuclei (arrow head). Multiple vacuoles (V) appears within the cells Group III (H. \& E. x400)

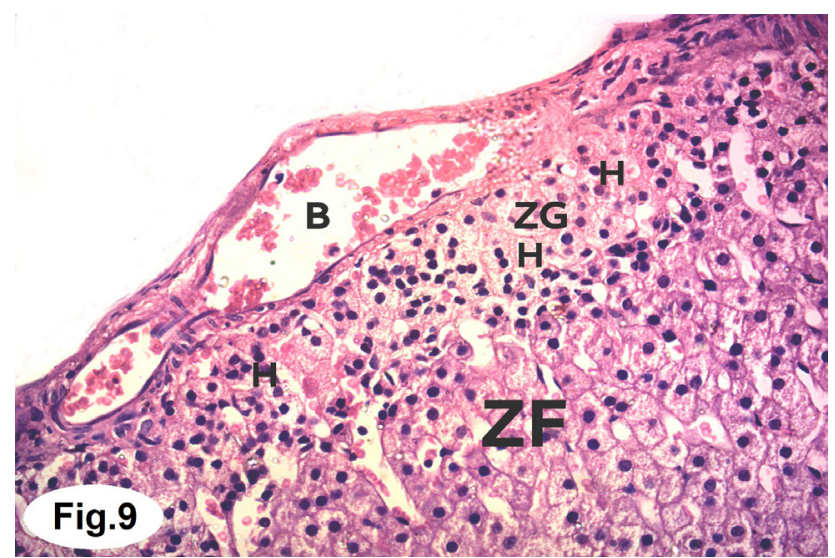

Fig. 9: A photomicrograph of adrenal cortex of adult male albino rat treated with streptozotocin showing dilated congested blood vessel (B). The cells of zona glomerulosa (ZG) and zona fasciculata (ZF) appears degenerated with hyalinization $(\mathrm{H})$ of their cytoplasm Group III (H. \& E.x400)

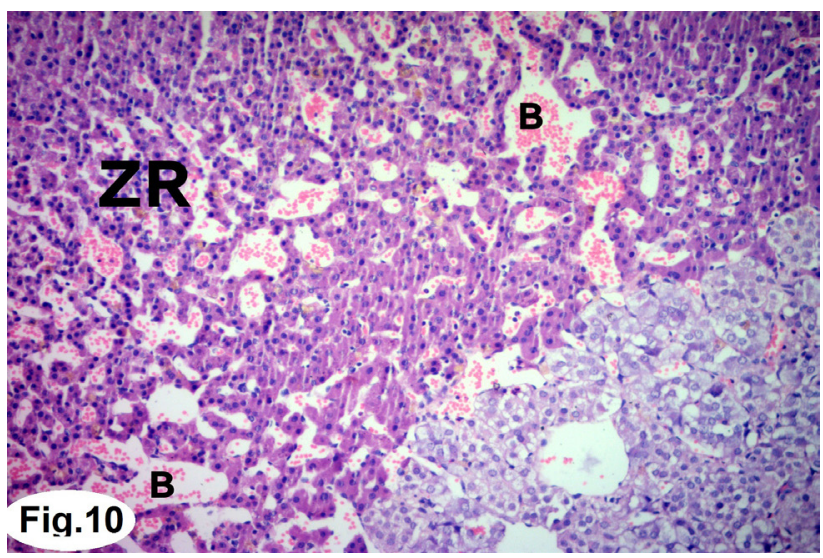

Fig. 10: A photomicrograph of zona reticularis (ZR) of adrenal cortex of adult male albino rat treated with streptozotocin showing multiple dilated congested blood sinusoids (B) in between its cells. Group III (H. \& E $\mathrm{x}$ 400)

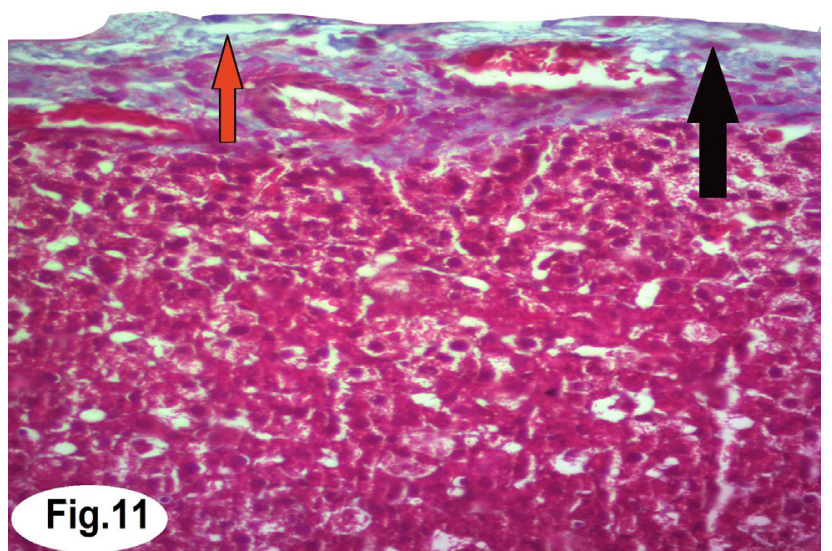

Fig. 11: A photomicrograph of adrenal cortex of adult male albino rat treated with streptozotocin showing apparent increase in the capsule thickness (black arrow) surrounding the gland with wide spaces between its fibers (red arrow). Group III (M.T x400)

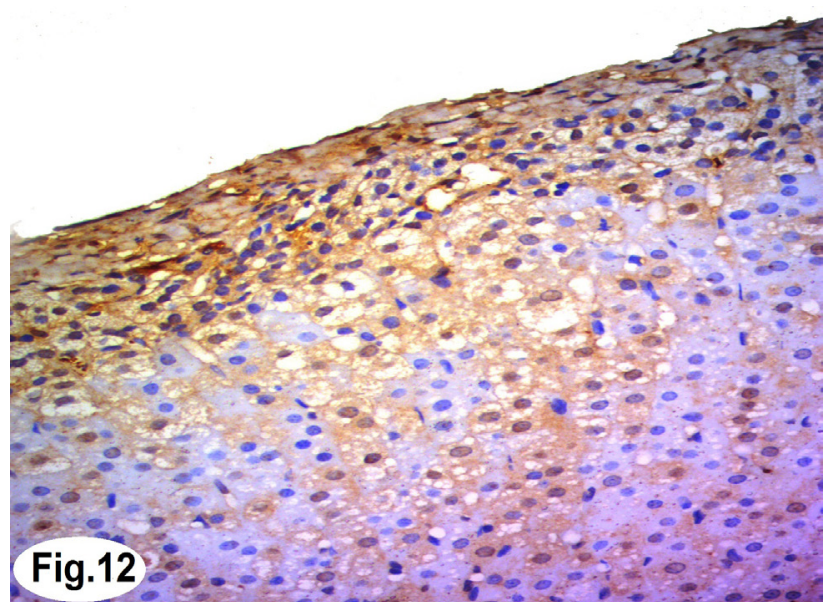

Fig. 12: A photomicrograph of adult adrenal cortex of streptozotocin treated group showing strong positive cytoplasmic immunoreactivity for caspase-3 within the cells of adrenal cortex. Group III (Caspase-3 x 400) 


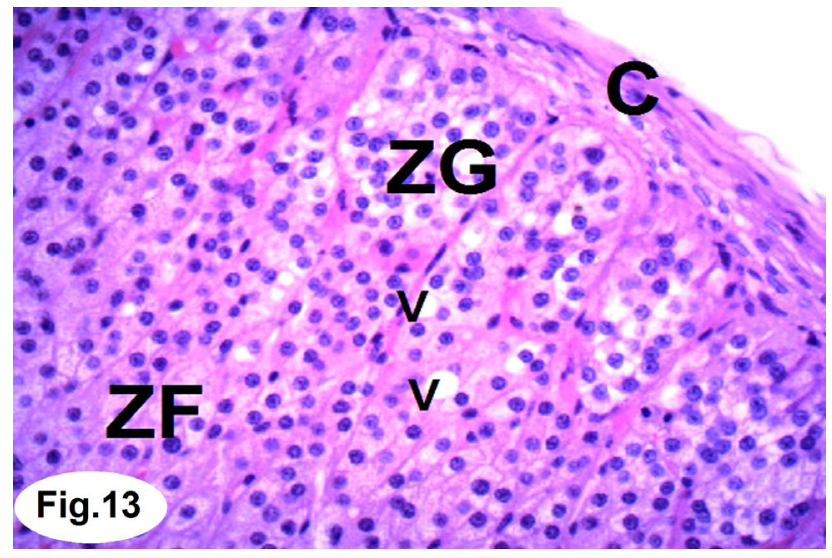

Fig. 13: A photomicrograph of adrenal cortex of adult male albino rats treated with barley grain and streptozotocin showing apparently normal capsule (C) surrounding the gland. The cells of zona glomerulosa (ZG) and zona fasciculata $(\mathrm{ZF})$ regain their normal arrangement. Notice some vacuoles (V) appear within the cells. Group IV (H. \&E. x 400)

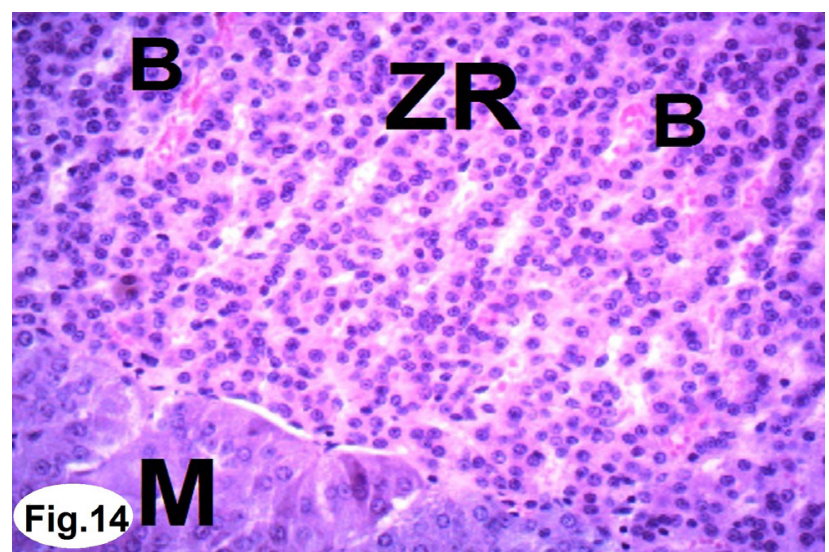

Fig. 14: A photomicrograph of central part of adrenal gland of adult male albino rat treated with barley grain and streptozotocin showing apparently normal anastomosing cords of zona reticularis (ZR) cells separated with blood sinusoids. Some dilated congested blood sinusoids (B) are still present. Medullary chromaffine cells are seen (M). Group IV (H. \& E. $\mathrm{x}$ 400)

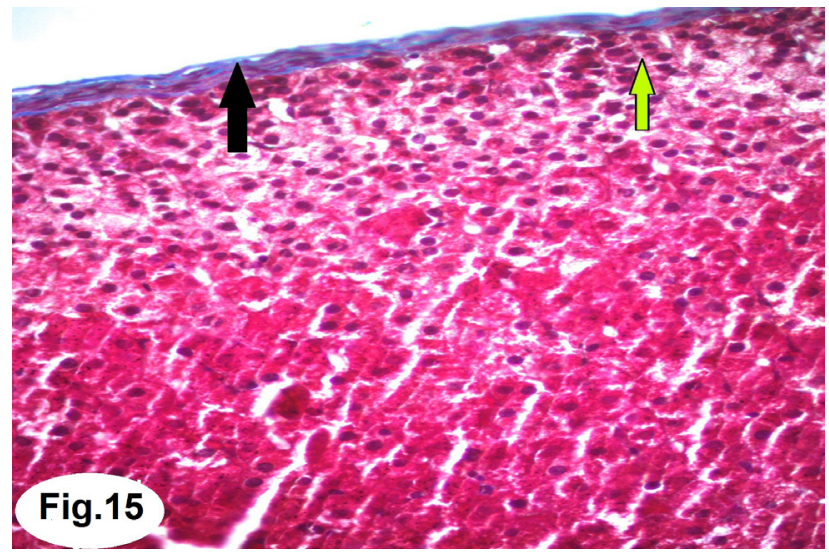

Fig. 15: A photomicrograph of adrenal cortex of adult male albino rat treated with barley grain and streptozotocin showing nearly similar amount of collagen fibers forming capsule (black arrow) to that in the control. Minimal amount of collagen fibers in the septa (yellow arrow) between the arches of zona glomerulosa appear. Group IV (M.T. x 400)

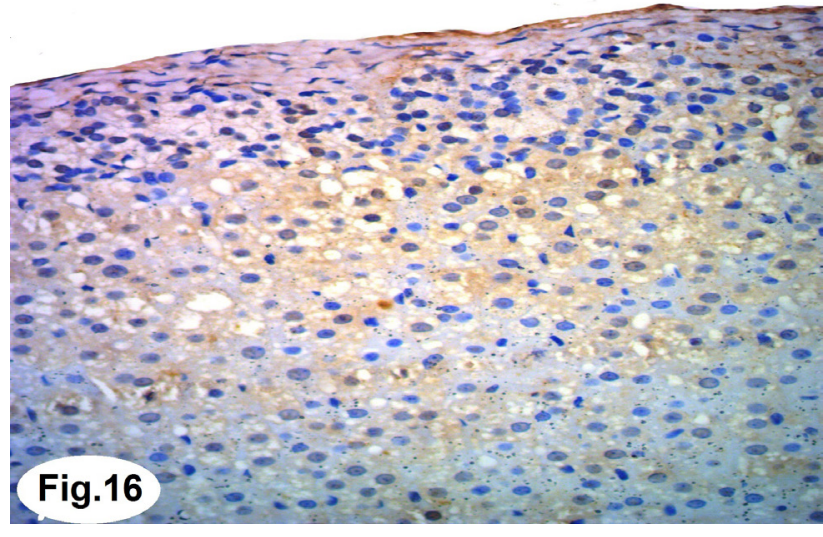

Fig. 16: A photomicrograph of adrenal cortex of adult male albino rat treated with barley grain and streptozotocin showing mild positive cytoplasmic immunoreactivity for caspase-3 within the cells of adrenal cortex. Group IV (Caspase-3 x400)

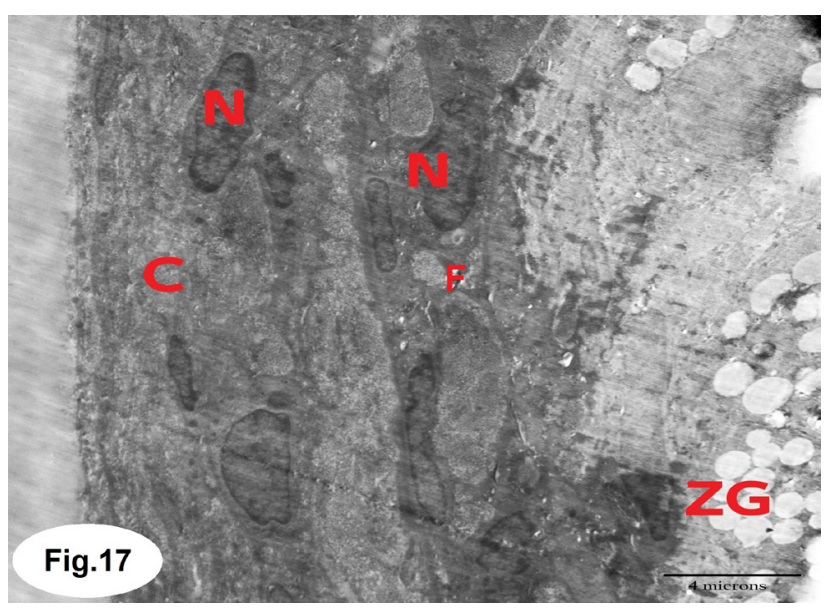

Fig. 17: An electron photomicrograph of the capsule surrounding adrenal gland of control group showing multiple oval nuclei $(\mathrm{N})$ of fibroblasts $(\mathrm{F})$ with normal contour and echogenicity. collagen fibers $(\mathrm{C})$ are arranged in-between. The cells of zona glomerulosa (ZG) with multiple lipid droplets are noticed under the capsule. Group I (TEM X 8000)

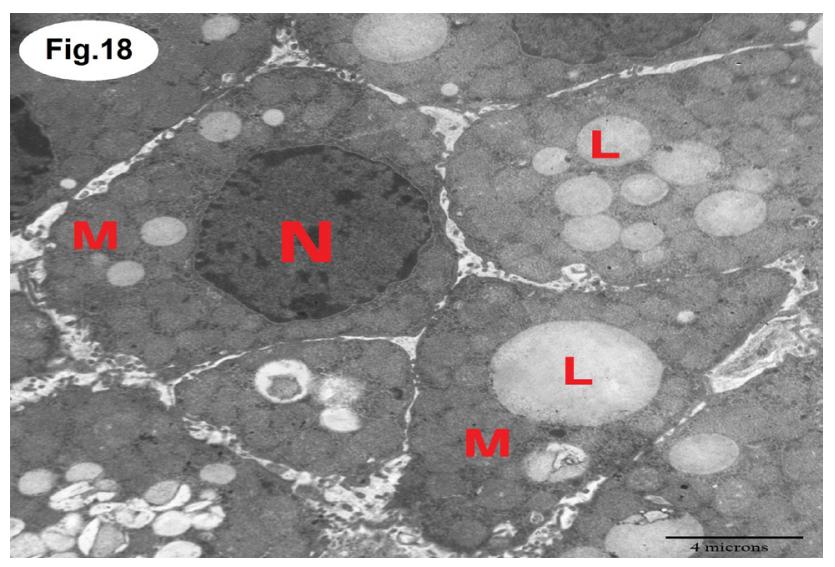

Fig. 18: An electron photomicrograph of adrenal cortex of control group showing some zona glomerulosa cells with rounded regular nuclei $(\mathrm{N})$. Multiple lipid droplets (L), as well as multiple globular mitochondria (M) are also noticed. Group I (TEM X 8000) 


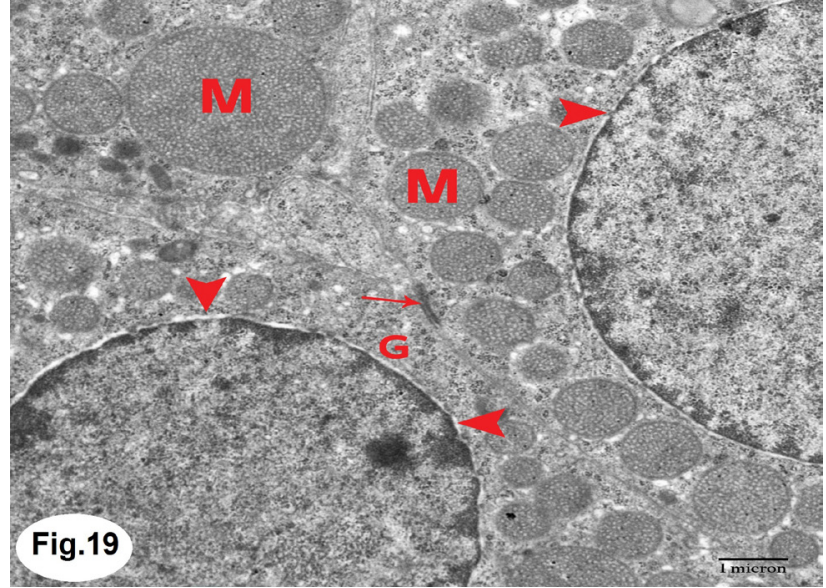

Fig. 19: An electron photomicrograph of zona glomerulosa cells of control group showing regular nuclear membrane (arrow head), multiple globular mitochondria (M) and rosette shaped glycogen electron-dense granules $(\mathrm{G})$. The desmosome junction between cells is noticed (arrow). Group I (TEM X 17500)

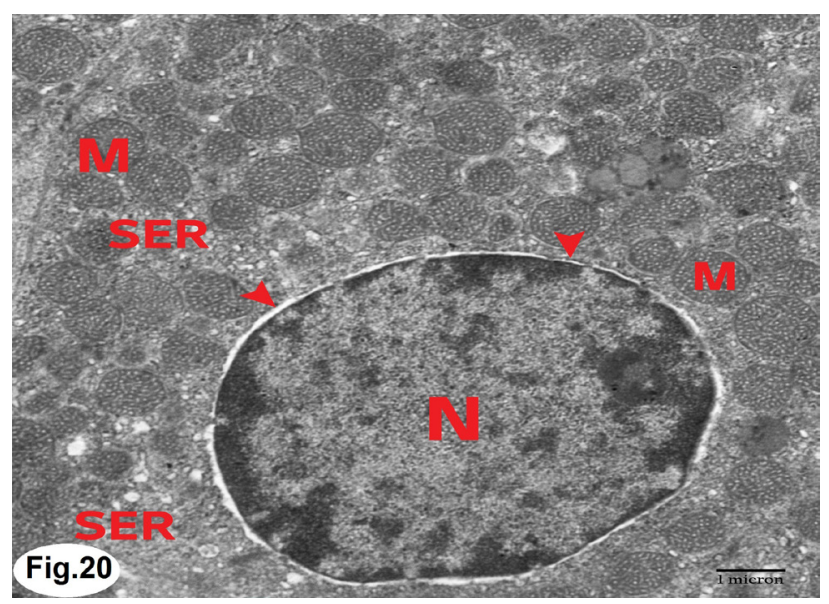

Fig. 20: An electron photomicrograph of zona fasciculata cells of control group showing normal rounded nucleus $(\mathrm{N})$ with regular double walled nuclear envelope (arrow head). Multiple globular mitochondria (M) and smooth endoplasmic reticulum (SER) are seen within the cytoplasm. Group I (TEM X 17500)

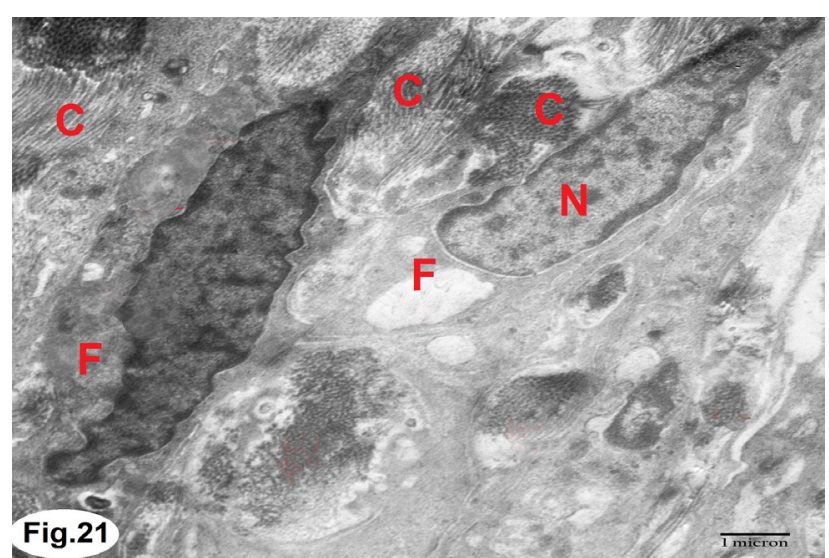

Fig. 21: An electron photomicrograph of the capsule of adrenal gland of streptozotocin treated group showing active fibroblast (F) with euchromatic nucleus $(\mathrm{N})$. Notice the presence of plenty of collagen fibres close to and nearby the fibroblasts (C) Group III (TEM X 17500)

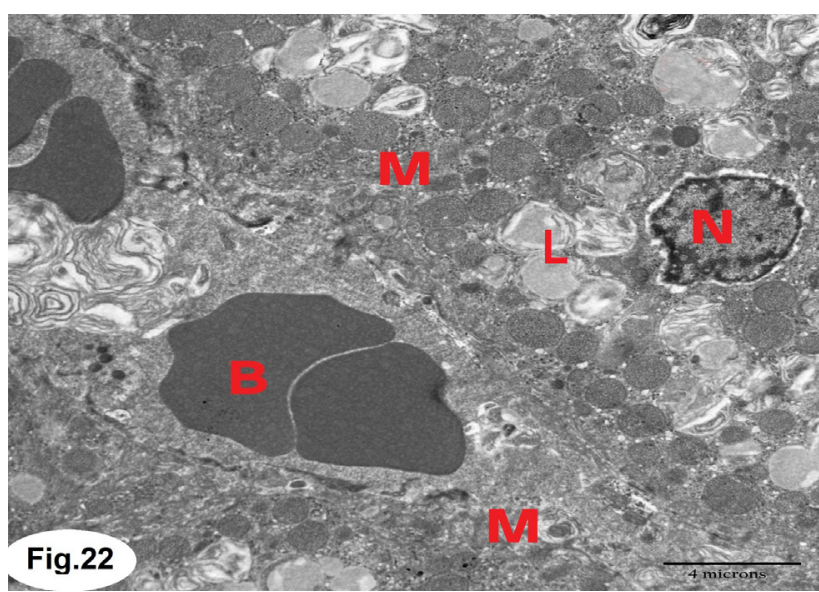

Fig. 22: An electron photomicrograph of zona glomerulosa cells of adrenal cortex of streptozotocin treated group showing shrunken nucleus (N) and degenerated mitochondria (M).lipid droplets (L) and congested blood vessel (B) are also seen Group III (TEM X 8000)

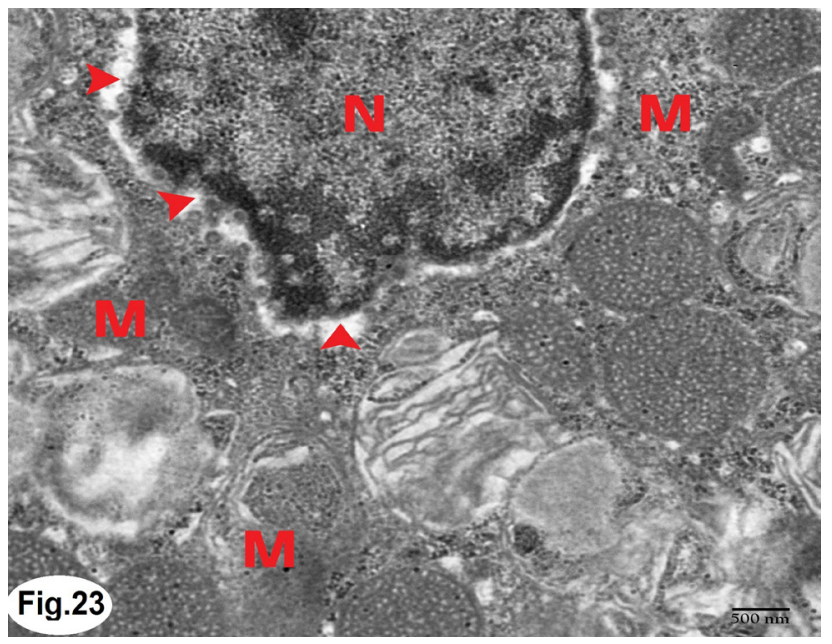

Fig. 23: Higher magnification of the previous photomicrograph showing degnerated nucleus $(\mathrm{N})$ with dilation of perinuclear space (arrow head). Marked mitochondrial swelling (M) is also noticed. Group III (TEM X 35000)

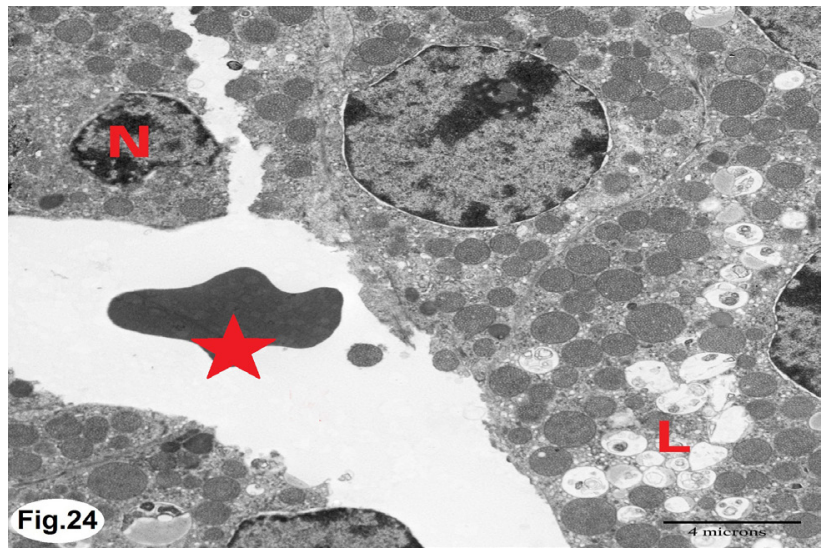

Fig. 24: An electron photomicrograph of zona glomerulosa cells of adrenal cortex of streptozotocin treated group showing large lytic area containing RBCs (star), shrunken degenerated nucleus (N) and multiple lipid droplets (L) with variable degrees of saturation. Group III (TEM X 8000) 


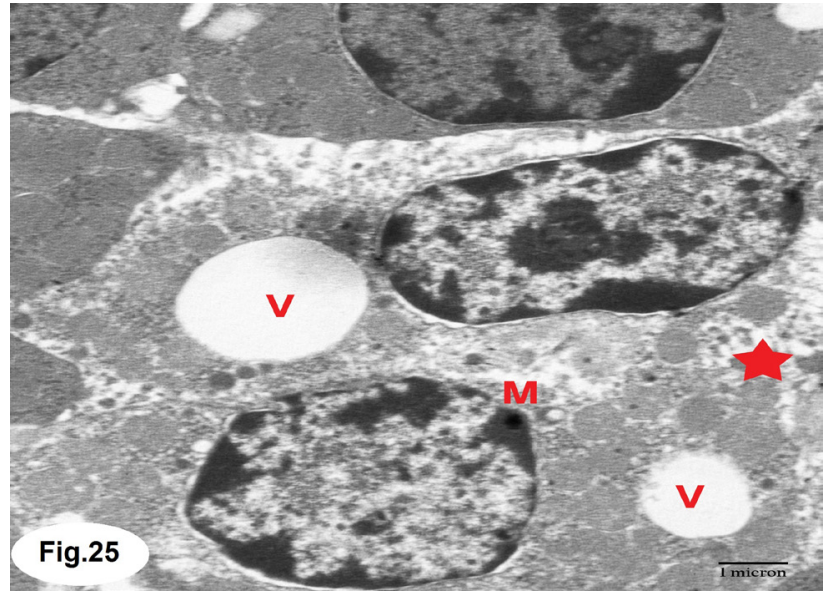

Fig. 25: An electron photomicrograph of zona fasciculata cells of adrenal cortex of streptozotocin treated group showing disorganized smooth endoplasmic reticulum (star) and mouse bitten mitochondria (M). Multiple vacuoles (V) are noticed within the cytoplasm of the cells. Group III (TEM X 17500)

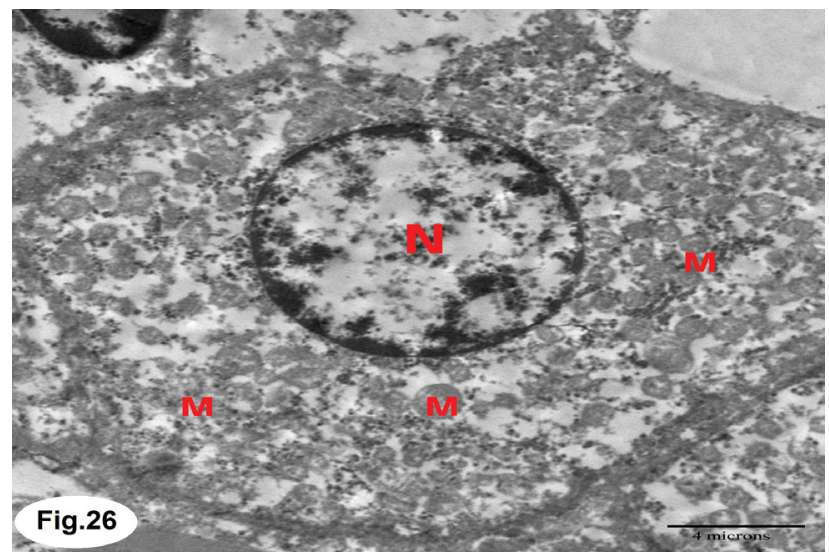

Fig. 26: An electron photomicrograph of zona fasciculata cells of adrena cortex of streptozotocin treated group showing marked rarefication of the cytoplasm, electron lucent nucleus $(\mathrm{N})$, partial and complete lysis of mitochondria (M). Group III (TEM X8000)

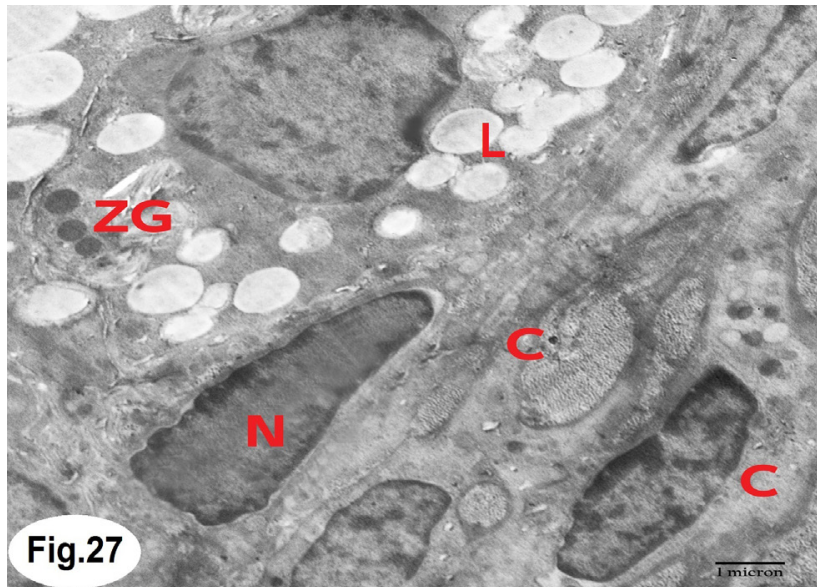

Fig. 27: An electron photomicrograph of the capsule of adrenal gland of barley grain and streptozotocin treated group showing normal nucleus (N) of fibroblast cells, with nearby collagen fibers (C). The cells of zona glomerulosa (ZR) with multiple lipid droplets (L) is noticed under the capsule. Group IV (TEM X 17500)

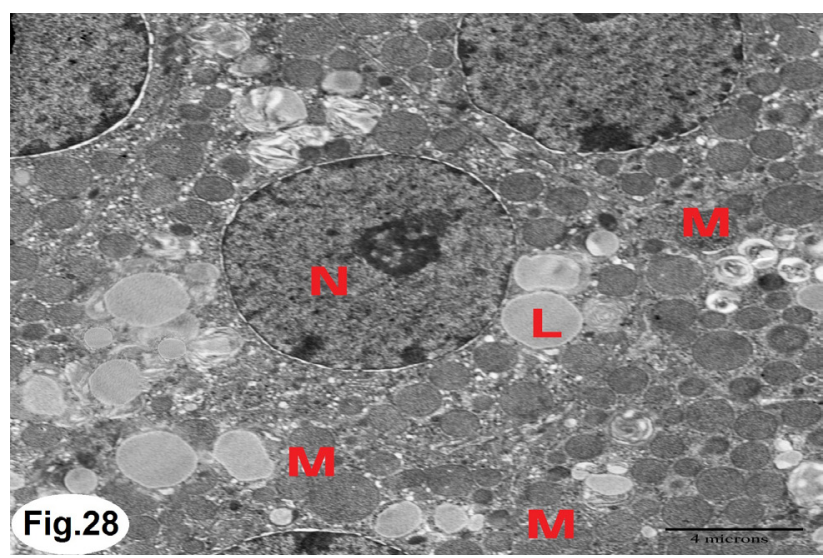

Fig. 28: An electron photomicrograph of zona glomerulosa cells of adrenal cortex of barley grain and streptozotocin treated group showing normal nuclei $(\mathrm{N})$, mitochondria $(\mathrm{M})$ and lipid droplets (L) are also seen. Group IV (TEM X 8000)

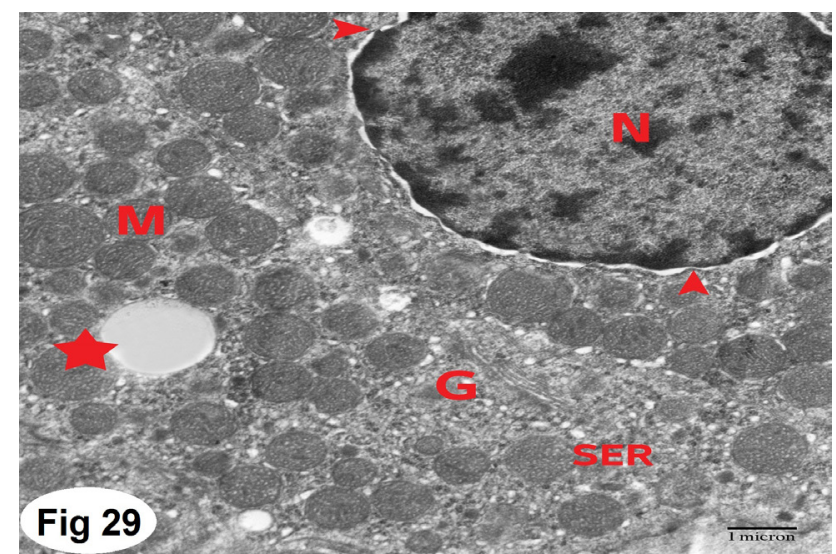

Fig. 29: An electron photomicrograph of zona fasciculata cells of adrenal cortex of barley grain and streptozotocin treated group showing euchromatic nucleus $(\mathrm{N})$, well-structured smooth endoplasmic reticulum (SER), apparently normal globular mitochondria (M) and well developed Golgi apparatus (G). A lipid droplet is seen within the cytoplasm (star) Group IV (TEM X 17500) 
Table 1: Comparison between different groups as regarding mean blood glucose level in $\mathrm{mg} / \mathrm{dl}$ at the $4^{\text {th }}, 8^{\text {th }}$ and $12^{\text {th }}$ weeks

\begin{tabular}{|c|c|c|c|c|c|c|c|c|c|}
\hline \multirow{2}{*}{$\begin{array}{l}\text { Experimental } \\
\text { groups }\end{array}$} & \multicolumn{9}{|c|}{ Blood glucose level (mg/dl) Mean \pm SD } \\
\hline & \multicolumn{3}{|c|}{$4^{\text {th }}$ week } & \multicolumn{3}{|c|}{$8^{\text {th }}$ week } & \multicolumn{3}{|c|}{$12^{\text {th }}$ week } \\
\hline Group I & \multicolumn{3}{|c|}{$120.4 \pm 2.1$} & \multicolumn{3}{|c|}{$118.9 \pm 3$} & \multicolumn{3}{|c|}{$122 \pm 2.8$} \\
\hline Group II & $112.6 \pm 16.6$ & T-test & Pvalue & $110 \pm 16.9$ & T-test & Pvalue & $109.4 \pm 21.6$ & T-test & Pvalue \\
\hline \multirow[t]{2}{*}{ Group III } & \multirow[t]{2}{*}{$261.6 \pm 6.9$} & $\mathrm{~T} 1=1.48$ & $\mathrm{P} 1=0.160$ & \multirow[t]{2}{*}{$268.3 \pm 7.9$} & $\mathrm{~T} 1=1.669$ & $\mathrm{P} 1=0.116$ & \multirow[t]{2}{*}{$311.5 \pm 17.6$} & $\mathrm{~T} 1=1.847$ & $\mathrm{P} 1=0.08$ \\
\hline & & $\mathrm{T} 2=97.187$ & $\mathrm{P} 2=0.001$ & & $\mathrm{~T} 2=86.588$ & $\mathrm{P} 2=0.001$ & & $\mathrm{~T} 2=46.855$ & $\mathrm{P} 2=0.001$ \\
\hline \multirow{2}{*}{ Group IV } & \multirow[t]{2}{*}{$122.5 \pm 5.4$} & $\mathrm{~T} 3=1.142$ & $\mathrm{P} 3=0.27$ & \multirow[t]{2}{*}{$119.2 \pm 4.4$} & $\mathrm{~T} 3=0.142$ & $\mathrm{P} 3=0.889$ & \multirow[t]{2}{*}{$122.3 \pm 2.2$} & $\mathrm{~T} 3=0.261$ & $\mathrm{P} 3=0.798$ \\
\hline & & $\mathrm{T} 4=75.926$ & $\mathrm{P} 4=0.001$ & & $\mathrm{~T} 4=79.617$ & $\mathrm{P} 4=0,001$ & & $\mathrm{~T} 4=47.037$ & $\mathrm{P} 4=0.001$ \\
\hline
\end{tabular}

- P1: comparison was done between control group (group I) and barely grain only treated group (group II).

- P2: comparison was done between control group (group I) and streptozotocin treated group (group III).

- P3: comparison was done between control group (group I) and barely grain and streptozotocin treated group (group IV).

- P4: comparison was done between streptozotocin treated group (group III) and barely grain and streptozotocin treated group (group IV).

- $P$ value $>0.05$ means "non-significant".

- $P$ value $<0.05$ means "significant"

- $P$ value $<0.001$ means "highly significant".

Table 2: Comparison between different groups as regarding mean body weight

\begin{tabular}{ccccc}
\hline & Group & Mean \pm SD & T.test & P.value \\
\hline & I & $212.4 \pm 8.78$ & T1 $=1.544$ & $\mathrm{P} 1=0.134$ \\
Body & II & $203.1 \pm 48.36$ & $\mathrm{~T} 2=23.77$ & $\mathrm{P} 2=0.001$ \\
Weight & III & $151.9 \pm 4.56$ & $\mathrm{~T} 3=1.77$ & $\mathrm{P} 3=0.08$ \\
In grams & IV & $206.1 \pm 11.33$ & $\mathrm{~T} 4=1.601$ & $\mathrm{P} 4=0.001$ \\
\hline
\end{tabular}

- P1: comparison was done between control group (group I) and barley grain treated group (group II).

- P2: comparison was done between control group (group I) and streptozotocin treated group (group III).

- P3: comparison was done between control group (group I) and barley grain and streptozotocin treated group (group IV).

- P4: comparison was done between streptozotocin treated group (group III) and barley grain and streptozotocin treated group (group IV).

- $P$ value $>0.05=$ Non significant

- $P$ value $<0.05=$ Significant

- $P$ value $<0.001=$ Highly significant

Table 3: Comparison between different groups as regarding mean adrenal weight

\begin{tabular}{ccccc}
\hline & Group & Mean \pm SD & T.test & P.value \\
\hline & I & $43.11 \pm 7.71$ & T1 $=1.36$ & $\mathrm{P} 1=0.185$ \\
Adrenal & II & $43.01 \pm 0.735$ & $\mathrm{~T} 2=6.01$ & $\mathrm{P} 2=0.001$ \\
weight & III & $55.09 \pm 0.66$ & $\mathrm{~T} 3=1.2$ & $\mathrm{P} 3=0.24$ \\
in mg. & IV & $46.69 \pm 8.48$ & $\mathrm{~T} 4=1.25$ & $\mathrm{P} 4=0.001$ \\
\hline
\end{tabular}

- P1: comparison was done between control group (group I) and barley grain treated group (group II)

- P2: comparison was done between control group (group I) and streptozotocin treated group (group III)

- P3: comparison was done between control group (group I) and barley grain and streptozotocin treated group (group IV).

- P4: comparison was done between streptozotocin treated group (group III) and barley grain and streptozotocin treated group (group IV).

- $P$ value $>0.05=$ Non significant

- $P$ value $<0.05=$ Significant

- $P$ value $<0.001=$ Highly significant
Table 4: Comparison between different groups as regarding mean serum aldosterone level

\begin{tabular}{ccccc}
\hline & Group & Mean $\pm \mathrm{SD}$ & T.test & P.value \\
\hline \multirow{2}{*}{ Serum } & I & $6.37 \pm 0.22$ & $\mathrm{~T} 1=1777$ & $\mathrm{P} 1=0.086$ \\
aldosterone & II & $6.18 \pm 0.34$ & $\mathrm{~T} 2=23.14$ & $\mathrm{P} 2=0.001$ \\
level $(\mu \mathrm{g} / \mathrm{dl})$ & III & $4.09 \pm 0.31$ & $\mathrm{~T} 3=1.904$ & $\mathrm{P} 3=0.067$ \\
& IV & $6.24 \pm 0.13$ & $\mathrm{~T} 4=1.61$ & $\mathrm{P} 4=0.001$ \\
\hline
\end{tabular}

Table 5: Comparison between different groups as regarding mean serum corticosterone level

\begin{tabular}{ccccc}
\hline & Group & Mean \pm SD & T.test & P.value \\
\hline & I & $8.42 \pm 0.29$ & T1 $=1.104$ & $\mathrm{P} 1=0.279$ \\
Seurm & II & $8.27 \pm 0.45$ & $\mathrm{~T} 2=24.6$ & $\mathrm{P} 2=0.001$ \\
corticosterone & III & $6.11 \pm 0.22$ & $\mathrm{~T} 3=1.06$ & $\mathrm{P} 3=0.296$ \\
level $(\mu \mathrm{g} / \mathrm{dl})$ & IV & $8.32 \pm 0.217$ & $\mathrm{~T} 4=1.05$ & $\mathrm{P} 4=0.001$ \\
\hline
\end{tabular}

- P1: comparison was done between control group (group I) and barley grain treated group (group II)

- P2: comparison was done between control group (group I) and streptozotocin treated group (group III).

- P3: comparison was done between control group (group I) and barley grain and streptozotocin treated group (group IV).

- P4: comparison was done between streptozotocin treated group (group

III) and barley grain and streptozotocin treated group (group IV).

- $P$ value $>0.05=$ Non significant

- $P$ value $<0.05=$ Significant

- $P$ value $<0.001=$ Highly significant

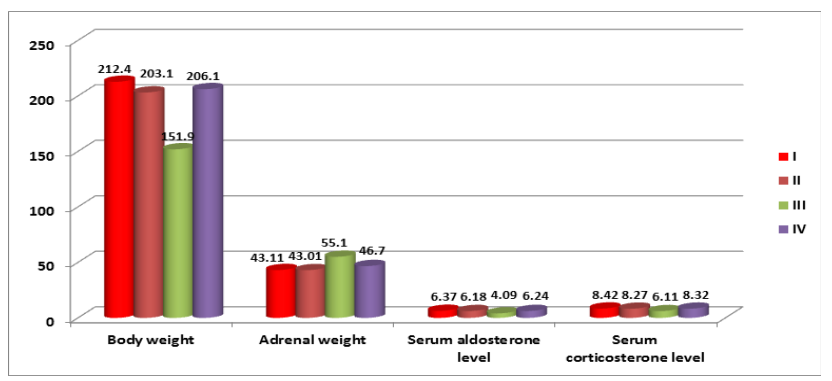

Diagram 1: Comparison between different groups as regarding means of body weight, adrenal weight, serum aldestrone level and serum corticosterone level 


\section{DISCUSSION}

Diabetes is one of the most common endocrine disorders. It is characterized by a state of hyperglycemia due to defect in the insulin secretion, insulin function or both, causing dysfunction in the body metabolism of carbohydrate, fats and proteins ${ }^{[20]}$.

Induction of diabetes was performed by a single intraperitoneal injection of streptozotocin (STZ). Streptozotocin is a pancreatic $\beta$-cell toxin causing rapid and irreversible necrosis of these cells ${ }^{[1]}$.

Some scientists reported that STZ causes $\beta$-cell injury by different mechanisms including excessive production of reactive oxygen species, lipid peroxidation, protein oxidation and DNA damage ${ }^{[21]}$

Another study demonstrated that formation of reactive oxygen species is thought to be a mediator of cytotoxic actions of STZ, leading to oxidative stress. Oxidative stress may be one of the stresses influencing the regulation of hypothalamic-pituitary-adrenocortical axis ${ }^{[1]}$.

The adrenal cortex has an important role in the activities of the human body. The adrenocortical zones synthesize and secrete steroid hormones as aldosterone and cortisone hormones that regulate and control metabolic processes within the major organ of the body ${ }^{[22]}$.

The aim of this study is to clarify the possible ameliorating effect of barley grain on the histological structure of adrenal cortex in STZ- induced diabetes.

In the present study, STZ- induced diabetes causes highly significant decrease in the rat's mean body weight and highly significant increase in mean adrenal weight. This is in agreement with the findings of the work of some scientists, who reported that diabetic rats had a significant reduction in their body weight and a significant increase in adrenal weight ${ }^{[22,23]}$. Some scientists attributed the reduction in body weight occurring with diabetes to excessive loss of tissue proteins, or deficiency of carbohydrate needed for the energy metabolism, which in turn leads to degradation of structural proteins and muscle wasting ${ }^{[24]}$.

The non-significant difference in the mean body weight between diabetic rats treated with barley grains compared with the control group might be due to the hypoglycemic role of barley grain resulting in normalization of blood glucose levels that prevent the loss of body weight.

The significant increase in mean adrenal weight may be attributed to increased adrenocorticotropic (ACTH) hormone level which occurs in turn by feedback mechanism as a result of reduced secretion of aldosterone and decreased corticosterone. The ACTH hypersecretion induces bilateral hyperplasia of the adrenal gland, leading to activation of extracellular signal regulated kinases (ERKs) and this play an essential role in cellular proliferation induction ${ }^{[25,26]}$.

Our findings showed that STZ- induced diabetes caused dilation and congestion of the blood vessels within the capusle.These results were in agreement with the experiment of some scientistes. They attributed the vasodilation of the blood vessels to oxidative stress caused by diabetes. This oxidative stress leads to the formation of advanced glycosylation end products. Reactive oxygen species (ROS) plays an important role in the pathogenesis of endothelial damage occuring with diabetes. Nitric oxide is one of the ROS and is produced by endothelial cells, which relaxes the smooth muscles; its increase results in vasodilation $^{[22,27]}$.

In Mallory stain of streptozotocin treated group, there was apparent increase in the thickness of the capsule with seperation of its collagen fibers. This was confirmed by the elctron microscopic results as plenty of collagen fibers were seen close to and near by the fibroblasts within the capsule. This may be due to increase collagen biosynthesis with diabetes as previously reported by the research of some scientistes who stated that there is a very significant rise in biosynthesis of total proteins espically collagen as an effect of high glucose concentration within rats $^{[28]}$.

In the streptozotocin treated group, the cells of the adrenal cortex appeared disorganized with pyknotic nuclei and vaculoated cytoplasm having disturbed smooth endoplasmic reticulum and degenerated mitochondria. The blood sinusoides in-between appeared dilated and congested. These results were in similarties with the results reported by diferrent groups of scientistes ${ }^{[29,30]}$. These results indicate apoptosis of the cells of adrenal cortex in STZ- induced diabetic rats that was confirmed by giving strong positive immunoreactivity of thses cells for caspase-3.

These changes may be related to cellular oxidative stress that plays major role in explenation of hyperglycemiarelated tissue damage ${ }^{[31]}$. Oxidative stress changes the structure and permeability of the cell membranes and intracellular organelles, such as mitochondria and the endoplasmic reticulum ${ }^{[32]}$. Reactive oxgyen species generation may also affect lysosomes and cellular DNA, making cells more susceptible to the damage caused by toxic products resulting in cellular death ${ }^{[33]}$. These changes detected within the cells of adrenal cortex results in decreased energy level and inhibition of steroidogenesis capacity of the cells of adrenal cortex in diabetes. These results were also confirmed by biochemical assessment of the seurm level of aldestrone and corticosterione that showed highly significant decrease in thier level with the diabetic group as compared with control group.

The diabetic rats treated with barley grain showed marked improvement in measurements of their mean body weight and mean adrenal weight and enhancement of the mean serum aldosterone and mean serum corticosterone level. They also, showed marked improvement in the histological appearance. These results indicate that hyperglycemia detected in STZ-induced diabetic rats was improved in barley grain treated diabetic rats. This was in agreement with the results of some researchers who 
reported that barley grain has hypoglycemic effect on diabetic rats ${ }^{[8,12]}$.

The hypoglycemic effect of barley grain was confirmed by measuring blood glucose levels of all groups at the $4^{\text {th }}$, $8^{\text {th }}$ and $12^{\text {th }}$ weeks. Group II (Barely grain treated group) and group IV (barley grain and streptozotocin treated group) showed non-significant difference in mean blood glucose level as compared with group I (control group). While group IV (Barley grain and streptozotocin treated group) showed highly significant decrease in mean blood glucose level as compared with group III (streptozotocin treated group).

The hypoglycemic effect of barley grain may be attributed to the fact that the barley grain is a great source of both soluble and insoluble fibers and the main protocols for diabetes management depends on dietary fiber intake ${ }^{[10]}$. Soluble fibers are effective in reducing the rate of sugar absorption, thus reducing the incidence for developing diabetes. The insoluble fibers help maintaining regular bowel function. Barley is a smart choice for diabetes management due to its high content of beta glycans. In fact, it has more beta glycan fiber than any other grain. Beta glycans decrease glucose absorption rate, keeping blood sugar levels stabilized. Also, beta glycans convert to gel-like substances when digested, giving the sense of being full for long time. Thus, results in less overeating, eating less with appetite reduction ${ }^{[34,35]}$.

Another study assumed that the hypoglycemic effect of barley grain may be due to its contents of amino acids and/or chromium salts ${ }^{[11]}$.

Barley is a main source of magnesium that acts as a co-factor for more than 300 enzymes that regulate glucose metabolism ${ }^{[36]}$.

Barley grain belongs to the grass family. It is a widely used cereal, because of its dietary health advantages, ready availability and low costs. History of barley consumption in the diet indicates its lack of toxicity ${ }^{[1]}$. Barley contains antioxidants, that reduce the rate of oxidative damage by scavenging free radicals ${ }^{[37]}$. Barley also has hepatoprotective and hypolipidemic effects ${ }^{[12]}$.

\section{CONCOLUSION}

Diabetis causes histological and biochemecal changes within the adrenal cortex, which was improved by barley grain adminstration

\section{CONFLICTS OF INTEREST}

There are no conflicts of interest

\section{REFERENCES}

1. Mahar, Y.; Shoro, A.A. and Hidayat, M.(2015):Effect of melatonin on the morphology of adrenal cortex altered by streptozotocin. P JMHS Vol.9, No.4. 1213-1216.
2. Hajarzadeh, A.; Jahromi, H.K.; Mokbber, H.; Jahromi, N.S.; Ghaedi, S. and Sadoughi, M. (2015): Studying histopathological effects of barely grain(Hordeum vulgare L.) on the evolution of the cortical portion of the adrenal glands in foetuses of diabetic albino rats. Comp Clin Pathol. 24:893-897.

3. El-feky, H.; Salah, A., Hussein, Y. and Sabry, M. (2010): Histological study of the effect of induced diabetes on the zona glomerulosa of the adrenal cortex of adult male albino rat". Egypt. J. Histol. Vol 33, No 1:17-22.

4. Raees, K.; Ishfaq, K.; Ullah, A.; Tahir, M.Z.; Abbas, T.; Tahir, H.M.; Mukhtar, M.K.; Arshad, M.; Khan, S.Y. and Ahmed, K.R. (2012): Histological and micrometric effects of diazinon exposure of adrenal medulla and cortex in mice". Journal of applied animal research, 40:4, 267-272.

5. Harvey, PW. (2010): Toxic responses of adrenal cortex In: Comprehensive Toxicology. Vol. 11, Reproductive and endocrine toxicology, 2nd edition. Elsevier Ltd. P. 265-289.

6. Al-Mahmood, SM.; Razak, T A.; Abdullah, ST.; Fatnoon, N N.; Mohamed , AH., and Al-Ain, IM.(2016):A Comprehensive study of chronic diabetes complications in streptozotocin-induced diabetic rat. Makara J. Health Res. 20(2):48-56.

7. Al-Hilfy, JH. (2013): Effect of green tea extract on histological structure of kidney, pancrease and adrenal gland in alloxan-induced diabetic male albino rats. Journal of Al- Nahrain University. Vol.16 (1):pp.156-165.

8. Abozalam, S A.; Salama, A. A.; Arbid, MS.; Ain Shoka, AA. and Abd El-latif, H, (2016): Effect of Barley, Green Tea and Doxorubicin against $\mathrm{N}$ dimethylnitrosamine Induced Hepatorenal Toxicity in Rats. Current Science International. Vol. 5:4. P: 386-399.

9. Fastnaught, C.E., Berglund, P.T, Holm, E.T and Fox, G.J (1996): Genetic and environmental variation in $\beta$-glucan content and quality parameters of barley for food. Crop Sci.; 36:941-946.

10. Brennan, C.S. and Cleary, L.J (2005): The potential use of cereal $(1 \rightarrow 3,1 \rightarrow 4)-\beta$-d-glucans as functional food ingredients". Journal of Cereal Science. 42, (1):1-13.

11. KhalajSereshki, Z.; Naseri, M.; Ghavami, B.; Naderi, G.A.; Kamali N. M; Faghihzadeh, S. et.al. (2010): Effect of barley (Hordeum vulgare L.) seed extract on fasting serumglucose level in streptozotocin induced diabetic rats. J Med Plants 34:57-66. 
12. Belal, N.M.(2011):Hepatoprotective effect of feeding celery leaves mixed with chicory leaves and barley grains to hypercholesterolemic rats. Asian J Clin Nutr; 3:14-24.

13. Al-dalalin, S.; El-kutry M.S and Ibrahim, H.S (2008):Inhibitory effect of aqueous extracts of barley and fenugreek on ulcer induction in rats. World Applied sciences journal 5(3):332-339. ISSN 1818-4952.

14. Kalleny, N.K. and Soliman, N.B. (2011):"Light and electron microscopic study on the effect of topically applied hyaluronic acid on experimentally induced corneal alkali burn in albino rats". Egyptian journal of histology. 34: 829-848.

15. Bancroft, J.D and Layton, C. (2010): "In: Theory and Practice of histological techinques". 7th edition. London: Churchill Livingstone, 173-214.

16. Bancroft, J.D and Gamble, M. (2007): Connective tissue stains. In: Bancroft, JD, Gamble,M. editors. Theory and practice of histological techniques. 6th ed. London, New york \&Philadelphia: Churchill livingstone. P: 150-155.

17. Sanii, S.; Saffar, H.; Tabriz, H.M., ; Qarbani, M.; Haghpanah, V. and Tavangar, S.M.( 2012): Asian Pac.J. Cancer prev., 13:2175-2167.

18. Glauert, A.M, and Lewis, P.R. (1998): Biological specimen preparation for transmission electron microscopy. $1^{\text {st }}$ ed. London: Portland Press.

19. Peat, J. and Barton, B. (2005): Medical statistics. A guide to data analysis and critical appraisal. First edition. Wiley- Blackwell. 113-119.

20. Elahi-Moghaddam, Z.; Behnam-Rassouli, M.; Mahdavi-Shahri, N.; Hajinejad-Boshroue,R. and Khajouee, E.(2013): Comparative study on the effects of type I and type II diabetes on the structural changes and hormonal output of the adrenal cortex in male wister rats. Journal of Diabetes \& Metabolic Disorders. Vol. 12:9.P:1-6.

21. Hidayat, M.; Mahar, Y. and Wasim, B. (2015): "Effect of melatonin on serum glucose and body weights in streptozotocin induced diabetes in albino rats" J Ayub Med Coll Abbottabad; Vol. Apr-Jun; 27(2):P: 274-6.

22. Abdel-Hamid, G.A.; Abdel-Aal, I.H. and El-Fark, M.O. (2015): Effect of green tea on the ultrastructure of the zona glomerluosa of the adrenal cortex in diabetic rats". The Egyptian Journal of histology. 38: 704-712.

23. Mustafa, GT.; Rosca, M.; Biemel, KM.; Reihl, O.; Smith, MA.;Viswanathan, A. et al., (2005): Paradoxical effects of green tea (Camellia sinensis) and antioxidant vitamins in diabetic rats: improved retionopathy and renal mitochondrial defects but deterioration of collagen matrix glycoxidation and cross linking. Diabetes (54): 517-526.

24. Shirwaikar, A.; Rajendran, K. and Barik, R. (2006): Effect of aqueous bark extract of Garuga pinnata Roxb. In streptozotocin-nicotinamide induced type-II diabetes mellitus. Journal Ethnopharmacol. 107: 285-290.

25. Ferreira, J.G.; Cruz, C.D.; Neves, D. and Pignatelli, D. (2007): Increased extracellular signal regulated kinases phosphorylation in the adrenal gland in response to chronic ACTH treatment. J. Endocrinol. 192: 647-658.

26. Lamounier, Z.V.; Bornstein, S.R.; Kunes, J; Zicha, J.; Kisek, M.; Ehrhart B.M. et al. (2008): Adrenocortical changes and arterial hypertension in lipoatropic A-ZIP/F-1mice. Mol Cell Endocrinol. 280:39-46.

27. Kumar, V.; Abbas, A.K. and Aster, J.C. (2012): Robbins basic pathology". 9th edition. Philadelphia. Elsevier Saunders Inc.

28. Bouguerra, S.A.; Benazzoug, Y.; Bekkhoucha, F. and Bourdillon, MC. (2004): Effect of high glucose concentration on collagen synthesis and cholesterol level in the phenotypic modulation of aortic cultured smooth muscle cells of sand rat(psammomys obesus). Experimental Diab. Res., 5:227-235.

29. Rebuffat, P.; Malendowicz, L.K.; Mazzocchi, G.; Gottardo, G. and Nussdorfer, G.G. (1990): Streptozotocin-induced expermintal diabetes causes a time- dependent inhibition of growth and steroidogenic capacity of rat adrenal zona glomerulosa. Res. Exp. Med.(Berl). 190:1-12.

30. Baraaj, A.H.(2015):Histological and biochemical changes in diabetic albino rats treated with soybean glycine max (L.) seeds. International journal of science and research. 6(6): 2507-2516.

31. Rees, M.D.; Kennett, E.C.; whitelock, J.M. And Davies, M.J.(2008):Oxidative damage to extracellular matrix and its role in human pathologies. Free Radic Biol Med. 44: 1973-2001.

32. Blokhina, O.; Virolainen, E. and Fagerstedt, K.V. (2003): Oxidative damage and oxygen deprivation stress: a review. Ann Bot 91:179-194.

33. Niedowicz, D.M. and Daleke, D.1. (2005): The role of oxidative stress in diabetic complications. Cell Biochem Biophys. 43:289-330.

34. Kovatcheva-Datchary, P.; Nilsson, A.; Akrami, R.; Lee, YS.; Vadder, F.; Arora, T.; Hallen, A.; Martens, E.; Björck, I. and Bäckhed, F. (2015): Dietary FiberInduced Improvement in Glucose Metabolism Is Associated with Increased Abundance of Prevotella. Cell Metabolism1;22(6):971-82 
35. Nilsson, A.C.; Johansson-Boll, E.V. and Bjorch, I.M. (2015): Increased gut hormones and insulin sensitivity index following a 3-d intervention with a barley kernel-based product: a randomised crossover study in healthy middle-aged subjects. British Journal of Nutrition; 114(6); 899-907.

36. Minaiyan, M.; Ghannadi, A.; Movahedian, A. and Hakim-Elahi, I. (2014): Effect of Hordeum vulgare
L. (Barley) on blood glucose levels of normal and STZ-induced diabetic rats". Res Pharm Sci. 9(3): 173-178.

37. Jeong, J.B.; Hong, S.C and Jeong, H.J.(2009): 4- dihydroxybenzaldehyde purified from the barley seeds (Hordeum vulgare) inhibits oxidative DNA damage and apoptosis via its antioxidant activity. Phytomedicine; 16:85-94. 
الملخص العربى

\section{التأثير المُحسّن المحتمل لحبوب الثُعير على التركيب النسيجي لقشرة الغدة الكظرية في داء السكري الناتج عن الستربتوزوتوسين في ذكور الفئران البيضاء البالغة}

\section{منى سليمان وداليا نوية}

\section{قسم الهستولوجيا و بيولوجيا الخليةـ كلية الطب -جامعة المنوفية}

الخلقية: يعد مرض السكري أحد اضطر ابات الغدد الصماء الأكثر شيو عًا التي تسببها قلة أو نقصان الأنسولين مما يؤدي إلى زيادة مستوى السكر في الدم و اضطر ابات التمثيل الغذائي في الجسم. مرض السكري بسبب ضمورشديد فى خلايا القشرة الكظرية. من المعروف أن حبوب الشعيرمفيدة في تنظيم استجابات السكر و الأنسولين و الكوليسترول للأطعمة. ومع ذللك ، فإن الدر اسات حول تأثثيره على تركيب القنرة الكظرية في مرض السكري محدودة الهدف من البحث: تقييم الدور الوقائى المحتمل لحبوب الثعير على التركيب النسيجى لقثرة الغدة الكظرية فى داء السكرى الناتج عن الستربتوزوتوسين فى ذكور الفئران البيضاء البالغة المواد و والطرق المستخدمة: تم استخدام اربعون من ذكور الفئران البيضاء البالغة فى هذا البحث و قد تم تقسيمهم إلى اربع مجمو عات(عشرة فئر ان فى كل مجمو عة)، المجموعة الأولى بمثابة المجموعة الضابطة. المجموعة الثانية: تلقت مستخلص الثعير، المجموعة الثالثة: تمت معالجتها بالستربتوزوتوسين لاحداث مرض السكرى، المجموعة الرابعة: تلقت مستخلص الثعير بعد احداث مرض السكرى وبعد r ا اسبوع تم ذبح الفئران و اخذ عينات من الدم للتحليل الهر مونى ثم تم تجهيز عينات من قشرة الغدة الكظرية لعمل در اسة نسيجية بو اسطة المجهر الضوئي و المجهر الإلكتروني و در اسة نسيجية مناعية. النتائج: لقد اظهرت الفئر ان المصابة بمرض السكري عن انخفاض ملحوظ في وزن الجسم وفى مستويات هرمونات الألدوستيرون و الكورتيكوستيرون وزيادة كبيرة في وزن الغدة الكظرية. وظهرت خلايا قثرة الغدة الكظرية غير

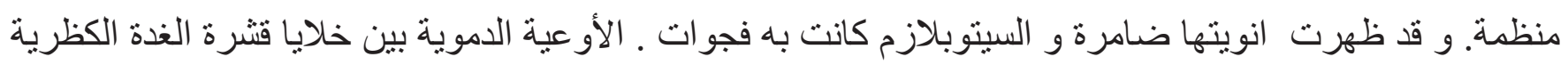
كانت متسعة ومحتقنة. و قد ظهرت الثبكة الاندوبلازمية الملساء و المينوكوندريا متحللة داخل الخلايا. بينما الفئران التى تلقت مستخلص الثعير بعد احداث مرض السكرى اظهرت تحسن واضح فى هذه التغييرات

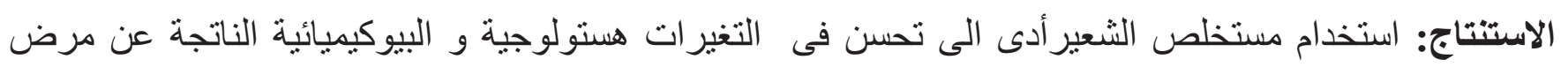
السكرى. 